\title{
Determinants of Sharia Banks' Return on Asset in ASEAN
}

Kiki Yunita Anjarsari ${ }^{1}$, Agus Eko Sujianto ${ }^{2 *}$, Mashudi ${ }^{2}$, Achmad Budi Susetyo ${ }^{1}$, Charina Dwi Rivylina ${ }^{1}$

${ }^{1}$ Magister of Sharia Economics, Institut Agama Islam Negeri Tulungagung, Indonesia

${ }^{2}$ Institut Agama Islam Negeri Tulungagung, Indonesia

DOI: $10.36347 /$ sjebm.2020.v07i08.004

| Received: 30.07.2020 | Accepted: 06.08.2020 | Published: 13.08.2020

*Corresponding author: Agus Eko Sujianto

Abstract

Original Research Article

This research aims to examine the factors that influence Return on Assets by using three indicators, Capital Adequacy Ratio (CAR), Islamic Corporate Social Responsibility (ICSR), and Gross Domestic Product (GDP). This study uses the Fixed Effect Panel Data Regression as the data analysis method. CAR and ICSR have a positive and significant effect on Return on Assets. However, GDP shows a negative and significant effect on Return on Assets. This means that the increase in GDP is inversely proportional to the amount of ROA obtained by Sharia Banks in ASEAN; when GDP increases, the ROA of a Sharia Bank decreases, and vice versa. Together, CAR, ICSR, and GDP have a positive and significant effect on ROA.

Keywords: Capital Adequacy Ratio, Islamic Corporate Social Responsibility, Gross Domestic Product, Return on Asset.

Copyright @ 2020: This is an open-access article distributed under the terms of the Creative Commons Attribution license which permits unrestricted use, distribution, and reproduction in any medium for non-commercial use (NonCommercial, or CC-BY-NC) provided the original author and source are credited.

\section{INTRODUCTION}

Globalization has made the practice of Islamic finance getting more and more globalized and received quite favorable responses from different countries in Asia, Africa, Australia, Europe, America, Canada, the Middle East, and other regions. Sharia banking is one of the most popular systems in the world with around 882 billion USD values. The 2015 Global Islamic Finance Report sets 5 criteria that are Advocacy, Infrastructure, Human Resources, Linkages, and Regulation. There are 10 countries designated as the Top 10 Centers of Excellence in Sharia Banking and Finance, namely Kuala Lumpur-Malaysia, Manama-Bahrain, DubaiUAE, London-United Kindom, Doha-Qatar, KuwaitKuwait, Karachi-Pakistan, Riyadh- Saudi Arabia, Jakarta-Indonesia, and Istanbul-Turkey [1].

The very rapid development of sharia banking also occurs in the Association of Southeast Asian Nations (ASEAN) region. Malaysia and Indonesia has become the dynamo of the development of sharia banking in the ASEAN region. In the context of the rapid development of sharia banks, Malaysia ranks first and Indonesia ranks ninth. But, the rapid development of sharia banking in the ASEAN region does not only occur in Malaysia and Indonesia, Brunei Darussalam which is predominantly Muslim also experiences a very rapid development of sharia banking.
The growth and development of sharia banks in a country's economy are mostly determined by the size of profits the banks obtained. The size of the profit reflects the large level of incentives obtained by sharia banks in carrying out its main function as an intermediary institution. The higher the level of profit obtained by a sharia bank, the greater the level of the bank's ability to develop its business. The achievement of profits in the sharia bank can be obtained through several factors, both internal and external.

Haron explained that the level of profitability of a sharia bank can be measured by the net profit of the business which is influenced by the bank's financial performance and macroeconomic conditions that occur in the economy of the country. The performance of sharia banking institutions shows the bank's ability to provide maximum profit levels in terms of assets, equity, and debt. One of the many ratios used by sharia banking to assess performance is the Return on Assets (ROA) ratio [2].

Meanwhile, according to research by Nurul [3], Dedy [4], Nanda and Hasan [5], Edward and Bernadin [6], I Gusti and Abundanti [7], Muhammad [8], Bushra [9], Muhammad [10], Platonova [11], Johan and Eka [12], Nurul and Ratna [13], Fauzizah and Dian [14], Cupian [15], Maysa'a [16], Siew and Sheikh [17], Qaisar [18], Ayu [19] and Dedi [20], the value of the ROA is empirically influenced by Capital Adequacy 
Ratio (CAR), Islamic Corporate Social Responsibility (ICSR), and Gross Domestic Product (GDP).

Based on the brief description above, the research questions are: (1) How does CAR influence ROA?; (2) How does ICSR influence ROA?; (3) How does GDP influence ROA?

\section{LITERATURE REVIEW}

Nurul examines the effect of CAR, BOPO, NPF, and CSR on the profitability of sharia banks using multiple linear regressions as the data analysis method. The results of this research indicate that there is a significant influence of CAR, BOPO, NPF, and CSR on the profitability of sharia banks [3]. The research that aims to examine the effect of CAR on the ROA of Sharia Commercial Banks winds that CAR significantly influences ROA in Sharia Commercial Banks [4]. Additionally, a study on CAR, BOPO, and ROA of Sharia Banks from 2011 to 2018 find that there is a significant effect of CAR on the ROA of Sharia Banks from 2012 to 2018 [5].

Next, research that examines the effect of CAR and LDR on ROA empirically finds that CAR has a significant effect on ROA [6]. Ambarawati and Abundanti's research shows that there is a significant effect of CAR on ROA [7]. Whereas Sufyan in his research showed that CAR and LDR significantly influence ROA in Rural Credit Banks in Indonesia [8].

$\mathrm{H}_{1}$ : CAR has a significant effect on the ROA of sharia banks in ASEAN.

Meanwhile, Bushra in his study found that CSR was positively and significantly related to financial performance [9]. This corresponds with Asraf's study which stated that CSR has a positive and significant influence on the financial performance of banks in ASIA [10]. In addition to the research conducted by Khan and Asraf, Platonova found that CSR has a positive and significant influence on financial performance in sharia banks. Concerning ROA [11], Johan and Eka on their study found that ICSR had a significant effect on ROA [12].

Nurul and Ratna on their research aim to find the effect of CSR on the profitability of sharia banks. The results showed that CSR significantly influenced the profitability of sharia banks [13]. Meanwhile, Fauzizah and Dian in their research aim to look for the influence of CSR on the company's reputation and financial performance. Their findings showed that CSR affects ROA [14].

$\mathrm{H}_{2}$ : ICSR significantly influences the ROA of sharia banks in ASEAN.
A study conducted by Cupian regarding the effect of macroeconomic variables on the profitability of sharia banks in Indonesia showed that the BI Rate, Inflation, and GDP affect the profitability of sharia banks [15]. Later on, Maysa'a in his study revealed that macroeconomic indicators (GDP) significantly influence profitability [16]. Siew and Sheikh studied the effect of inflation and GDP on the profitability of sharia banks in Malaysia. From the research results, it is known that GDP shows a significant and positive effect on the profitability of sharia banks in Malaysia [17]. On the same hand, Qaisar in his research on the influence of macroeconomics on the profitability of Sharia Banks in Brunei Darussalam using the Panel Regression technique concluded that inflation and GDP contributed positively and significantly to the profitability of Sharia Banks in Brunei Darussalam [18]. Ayu also conducts a study on the effect of GDP on Sharia Bank ROA in Indonesia using the Multiple Linear Regression Technique. The results obtained in the study indicate that GDP and Inflation have a positive and significant effect on the profitability of sharia banks in Indonesia [19].

$\mathrm{H}_{3}$ : GDP has a significant effect on the ROA of sharia banks in ASEAN.

\section{METHODOLOGY}

The population in this study is 39 Sharia Banks in ASEAN. The sample in this study is selected through the purposive sampling technique with the following criteria: (1) data limitation on each Sharia Bank from each country from 2012 to 2018; (2) the data is documented in numeric format; (3) the banks that published the secondary data are responsible and competent, and (4) banks with the highest asset value in each country. Based on the criteria, a sample of 9 sharia banks from 3 countries in the ASEAN region was chosen. The samples consist of Bank Muamalat Indonesia, Bank Syariah Mandiri, Bank Negara Indonesia Syariah, Bank Rakyat Indonesia Syariah, Maybank Islamic Berhad in Malaysia, Malaysia Islamic Bank Berhad, CIMB Islamic Berhad in Malaysia, Affin Sharia bank in Malaysia, and Brunei Darussalam Islamic Bank in Brunei Darussalam. This study uses time-series data for 2012 to 2018 observations. The data is analyzed using panel data regression. Data were transformed the econometrics analysis due to differences in the unit of measure in the form of percentages and ratios.

\section{RESULTS AND DISCUSSION \\ Residual Normality Test}

The normality test in this study was conducted using the Jaraque-Berra (JB) test. The test results indicate that the value of $\mathrm{JB}=2.206330$ with a probability of 0.909178 . Thus, it can be concluded that the data of this study are normally distributed. 


\section{Multicollinearity Test}

Multicollinearity test is used to determine the linearity of the relationship of each independent variable in the regression model under the condition that if the value of Variance Inflation factor $(\mathrm{VIF})<10$, Multicollinearity does not occur.

Table-1: Multicollinearity Test Results

\begin{tabular}{|c|c|c|}
\hline Variables & VIF & Results \\
\hline CAR & 1,045 & Non Multikolinearitas \\
\hline ICSR & 1,066 & Non Multikolinearitas \\
\hline GDP & 1,092 & Non Multikolinearitas \\
\hline
\end{tabular}

\section{Heteroscedasticity Test}

The heteroscedasticity test is used to see the presence or the absence of heteroscedasticity in a model. The heteroscedasticity test in this study is performed through the Breusch Pagan Godfrey method, with the provisions that if the probability value> 0.05 , heteroscedasticity does not occur and if the Probability value $<0.05$, heteroscedasticity occurs.

Table-2: Heteroscedasticity Test Results

\begin{tabular}{|c|c|c|c|}
\hline Statistic test & Obs*R-squared & Probability. & Results \\
\hline Breusch Pagan Godfrey & 5,7595 & 0,1239 & Heteroscedasticity does not occur \\
\hline
\end{tabular}

\section{Autocorrelation Test}

Autocorrelation testing in this study was carried out using the Chi-Square method, where if the probability Chi-Square value $>0.05$, it can be said there is no autocorrelation problem and if the Prob ChiSquare value $<0.05$, then there is an autocorrelation problem.

Table-3: Autocorrelation Test Results

\begin{tabular}{|c|c|c|c|}
\hline F-statistic & $\mathbf{1 . 2 8 3 5 6 8}$ & Prob. F(2,57) & $\mathbf{0 . 2 8 4 9}$ \\
\hline Obs*R-squared & 2.715080 & Prob. Chi-Square(2) & 0.2573 \\
\hline
\end{tabular}

Selection of Regression Model using the Chow Test

The Chow Test is used to determine whether it is the Common Effect Model or Fixed Effect Model that will be used in this study. The model selection is done through the Chow Test method using the following guidelines:

\section{$\mathrm{H}_{0}$ : Common Effect Model \\ $\mathrm{H}_{1}$ : Fixed Effect Model}

When the value of the probability of the CrossSection Chi-Square $<0.05$, the Fixed Effect Model will be selected and when the value of the probability of the Cross-Section Chi Square> 0.05, the Common Effect Model will be chosen.

Table-4: Chow Test Results

\begin{tabular}{|c|c|c|c|}
\hline Effects Test & Statistic & d.f. & Prob. \\
\hline Cross-section F & 2.815121 & $(8.51)$ & 0.0115 \\
\hline Cross-section Chi-square & 23.041938 & 8 & 0.0033 \\
\hline
\end{tabular}

Based on the test results above, it can be seen that the Chi-Square Cross-Section Prob value is 0.0033 $<0.05$, it indicates that the $\mathrm{H} 1$ hypothesis is accepted so that the regression model that will be used is the Fixed Effect Model.

\section{Selection of Regression Model using the Hausman Test}

The Hausman test is used to determine whether it is the Random Effect Model or Fixed Effect Model that will be used in this study using the following guidelines:

H0: The model used is the Random Effect Model

H1: The model used is the Fixed Effect Model

If the value of Cross Section Random Probability $<0.05$ then the selected model is the Fixed Effect Model and if the value of Cross Section Random Probability $>0.05$ then the selected model is the Random Effect Model.

Table-5: Hausman Test Results

\begin{tabular}{|c|c|c|l|}
\hline Test Summary & Chi-Sq. Statistic & Chi-Sq. d.f. & Prob. \\
\hline Cross-section random & 12.221019 & 3 & 0.0067 \\
\hline
\end{tabular}


Based on the test results above, it can be seen that the value of Prob Gross Section Random is 0.0067 $<0.05$, indicating that the hypothesis received by $\mathrm{H} 1$, which means the regression model used is the Fixed Effect Model.

\section{Regression Analysis}

Based on the results of panel data analysis with Eviews 10 software, there are three estimation methods testing, namely Chow Test, Hausman Test, and Lagrange Multiplier, the Fixed Effect model shows that this model is the best. The following are the results of the Fixed Effect Model panel data regression test.

Table-6: Fixed Effect Model Data Regression Panel Test Results

\begin{tabular}{|c|r|r|r|l|}
\hline Variables & Coefficient & Std. Error & t-Statistic & \multicolumn{1}{l|}{ Prob. } \\
\hline C & 15.89285 & 4.533387 & 3.505734 & 0.0010 \\
\hline CAR & 0.132697 & 0.113830 & 1.165744 & 0.2491 \\
\hline ICSR & 0.019234 & 0.051434 & 0.373953 & 0.7100 \\
\hline GDP & -1.641774 & 0.498944 & -3.290501 & 0.0018 \\
\hline R-Square & 0.532564 & & & \\
\hline Adjusted R-Squared & 0.431744 & & & \\
\hline F-Statistic & 5.282348 & & & \\
\hline Prob(F-statistic) & 0.000017 & & & \\
\hline
\end{tabular}

Based on table 6, it can be stated that the RSquare value of CAR, ICSR, and GDP, is 0.532564 or $54.26 \%$. This means that the CAR, ICSR, and GDP variables have a large contribution to the amount of ROA obtained by Sharia Banks in ASEAN. The remaining $46.74 \%$ is influenced by other factors that are not included in this research. Thus the results of the analysis of the fixed-effect model, the regression equation can be written as follows:

$\mathrm{ROA}=15.89285+0.132697 \mathrm{CAR}+0.019234 \mathrm{ICSR}-$ 1.641774 GDP

\section{DISCUSSION}

The results of this study statistically proved that there is a non-significant and positive effect of CAR on the profit of sharia banks in ASEAN. This result contradicts the previous research proposed by Nurul [3], Dedy [4], Nanda and Hasan [5], Edward and Bernardin [6], I Gusti and Abundanti [7], and Muhammad [8] who explains that there is a significant influence of CAR on ROA. Therefore, the first hypothesis which stated that CAR has a significant effect on the ROA of Sharia Banks in ASEAN is not supported.

The contribution of ICRS to ROA is positive and non-significant. These results contradict the research conducted by Bushra [9], Muhammad [10], Johan and Eka [12], Nurul and Ratna [13], and is not relevant to research done by Fauzizah and Dian [14]. Therefore, the second hypothesis stated that ICSR has a significant effect on the ROA of sharia banks in ASEAN is not supported. Further, this study also found that there is a significant and negative effect of GDP on the ROA of Sharia Banks in ASEAN. Therefore, this finding does not support the study conducted by Cupian [15], Maysa'a [16], and Ayu [19] so that the third hypothesis, GDP has a significant effect on ROA of Sharia Banks in ASEAN is not supported.

\section{CONCLUSION AND RECOMMENDATION}

The findings of the analysis in this research are, first, there is a positive and significant effect of CAR on the ROA of sharia banks in ASEAN. The level of CAR affects the amount of ROA generated by sharia banks in ASEAN. Second, ICSR has a positive and significant effect on the ROA of sharia banks in ASEAN. Zakat is a part of ICSR. Third, GDP has a negative and significant effect on the amount of ROA of sharia banks. This is asymmetrical with the existing theory that the increase of GDP will be followed by the increase in the levels of public income so that the people's ability to save also experiences an increase and therefore also increasing the level of profitability of sharia banks. Fourth, simultaneously, CAR, ICSR, and GDP have a positive and significant impact on the ROA of sharia banks in ASEAN.

It is recommended to the management of sharia banks to maintain capital (CAR) with the standards set by the Banking for International Settlement (BIS) so that the operational activities can continue to run well without any obstacles in terms of capital and bank maximum profitability can be obtained. Good management of the surrounding environment has a positive effect on financial performance, so it is recommended to strengthen the ICSR of the company. Macroeconomic indicators also need to be considered in increasing company profitability, and it is recommended to provide financing in the real sector.

\section{REFERENCES}

1. Aisyah AM. Perkembangan Perekonomian Islam Beberapa Negara di Dunia, Jurnal Diponegoro Private Law Review. 2019; 4(1).

2. Sulhan H. Determinasint of Islamic Bank Profitability. Working Paper Series, No 002. Global Journal of Finance and Economics. USA. 2014;1(1). 
3. Nurul R. Pengaruh CAR, BOPO, NPF dan CSR Disclosure terhadap Profitabilitas Perbankan Syariah. Jurnal Ilmiah Wahana Akuntansi. 2013;8(2).

4. Dedy M. Pengaruh CAR terhadap ROA pada BUS, Jurnal Ekonomi dan Bisnis Islam IAIN Samarinda. 2017;3(1).

5. Nanda AS and Hasan F. Pengaruh CAR dan BOPO terhadap ROA pada Bank Syariah pada tahun 2012-2018. Journal Islamic Banking \& Finance. 2019;2(1).

6. Edwar D and Bernadin Y. Pengaruh CAR dan LDR terhadap ROA. Journal Ecodemica. IV (2); 2016.

7. I Gusti ADA and Abundanti N. Pengaruh CAR, NPL dan LDR terhadap ROA. Jurnal Manajemen Unud. 2018;7(5).

8. Muhammad S. Analysis Financial Performance of Rural Bank in Indonesia. International Journal of Economic Business and Accounting Reseach (IJEBAR). 2019;3(3).

9. Bushra K. Corporate Social Responsibility Impact on Financial Performace of Islamic and Conventional Banks: Ecidence from Asia Countries. Journal of Finance and Accounting Departemen of Management Science University of Gujrat, Sub Campus Narowal. 2017;8(7).

10. Muhammad A. Corporate Social Responsibility impact to Financial Performace of Banks Evidence from Asia Countries. International Journal of Academic Reseach in Business and Social Science. 2017;7(4).

11. Platonova E. The Impact of Corporate Social Responsibility Disclosure on Financial Performance: Evidence from the GCC Islamic Banking Sector. J.Bus Ethic. 2018;7(2).
12. Johan A and Eka A. Islamic Corporate Social Responsibility Disclosure, Reputasi dan Kinera Keuangan. Jurnal Akuntansi dan Auditing Indonesia. 2016; 20(1).

13. Nurul R and Ratna A. Pengaruh CAR, BOPO, NPF dan CSR terhadap Profitabilitas Perbankan Syariah. Jurnal Ilmiah Wahana Akuntansi. 2013;8(2).

14. Fauzizah NN and Dian K. Pengaruh CSRD terhadap Reputasi dan Kinerja Keuangan Perusahaan. Jurnal Ilmu Manajemen dan Akuntansi Terapan. 2017; 8(2).

15. Cupian A. The Impact of Macroeconomic Variables on Indonesian Islamic Banks Profitability. Jurnal Ekonomi dan Bisnis Unoiversitas Pandjajaran. 2016; 2(2).

16. Maysa'a M. The Impact of Macroeconomic Varoables on Banks Profitability and Liquidity an Empirocal Study on Islamic and Conventional Banks in Jordan, Journal Economic and Management Perspektives. 2018; 2(306-318).

17. Siew $\mathrm{CH}$ and Sheikh HAR. The Impact of Nominal GDP and Inflastion on the Financial Performance of Islamic Bank in Malaysia. Journal of Islamic Economic, Banking \& Finance. 2015; 11(1).

18. Qaisar A. Impact of Macroeconimic Variables on Islamic Banks Profitability. Journal of Accounting and Applied Business Research. 2018; 1(2).

19. Ayu YS. Analisis Pengaruh Inflasi, Suku Bunga BI dan GDP terhadap ROA Bank Syariah di Indonesia. Jurnal Ilmu Manajemen. 2013; 1(1).

20. Dedi S. Islamic Bank Profitability: A Study of Islamic Bank in Indonesia. International Journal of Business. 2018; 1(1). 